NBER WORKING PAPER SERIES

THE GREAT RECESSION, RETIREMENT AND RELATED OUTCOMES

\author{
Alan L. Gustman \\ Thomas L. Steinmeier \\ Nahid Tabatabai \\ Working Paper 20960 \\ http://www.nber.org/papers/w20960
NATIONAL BUREAU OF ECONOMIC RESEARCH
1050 Massachusetts Avenue
Cambridge, MA 02138
February 2015

We gratefully acknowledge support for this research from a grant provided by the Sloan Foundation to Dartmouth College. The findings and conclusions expressed are solely those of the authors and do not represent the views of the Sloan Foundation. The views expressed herein are those of the authors and do not necessarily reflect the views of the National Bureau of Economic Research.

NBER working papers are circulated for discussion and comment purposes. They have not been peerreviewed or been subject to the review by the NBER Board of Directors that accompanies official NBER publications.

(C) 2015 by Alan L. Gustman, Thomas L. Steinmeier, and Nahid Tabatabai. All rights reserved. Short sections of text, not to exceed two paragraphs, may be quoted without explicit permission provided that full credit, including (C) notice, is given to the source. 
The Great Recession, Retirement and Related Outcomes

Alan L. Gustman, Thomas L. Steinmeier, and Nahid Tabatabai

NBER Working Paper No. 20960

February 2015

JEL No. E24,E32,J11,J14,J21,J26,J4,J6,J63,J64,J82

\begin{abstract}
This paper uses data from the Health and Retirement Study to examine retirement and related labor market outcomes for the Early Boomer cohort, those in their mid-fifties at the onset of the Great Recession. Outcomes are then compared with older cohorts at the same age.

The Great Recession increased their probability of being laid off and the length of time it took to find other full-time employment. Differences in layoffs between those affected by the recession and members of older cohorts in turn accounted for almost the entire difference between cohorts in employment change with age. The Great Recession does not appear, however, to have depressed the wages in subsequent jobs for those who experienced a layoff.

In 2010, 17 percent of the Early Boomers were Not Working and Not Retired or Partially Retired, and 6 percent were unemployed, leaving at least 9 percent who were not working and not unemployed but not retired or only partially retired.

At the recession's peak, half of those who experienced a layoff ended up in the Not Retired or Partially Retired, Not Working category. But only a quarter of those who declared themselves to be Not Retired or Partially Retired, and were Not Working, had experienced a layoff. Most of the jump in Not Retired or Partially Retired, Not Working appears to reflect a change in expectations about the potential or need for future work, a change that is not the result of an actual job loss.
\end{abstract}

\author{
Alan L. Gustman \\ Department of Economics \\ Dartmouth College \\ Hanover, NH $03755-3514$ \\ and NBER \\ ALAN.L.GUSTMAN@DARTMOUTH.EDU \\ Thomas L. Steinmeier \\ Department of Economics \\ Texas Tech University \\ Lubbock, TX 79409 \\ thomas.steinmeier@ttu.edu
}

\author{
Nahid Tabatabai \\ Department of Economics \\ Dartmouth College \\ Hanover, N.H. 03755 \\ Nahid.Tabatabai@dartmouth.edu
}


This paper uses panel data from the Health and Retirement Study (HRS) to analyze changes in the course of retirement and related labor market outcomes brought on by the Great Recession. The population studied was approaching retirement at the onset of the recession.

Recent studies have documented the effects of various stages of the Great Recession on particular labor market and retirement related outcomes. For example, Coile and Levine (2011a and b), Johnson (2012), Burtless and Bosworth (2013), Gorodnichenko, Song and Stolyarov (2013) and Copeland (2014) have each considered the effects of the Great Recession on some measure of retirement or employment status. ${ }^{1}$

In an effort to increase understanding of the effects of the Great Recession on retirement and related labor market outcomes, we attempt a more comprehensive analysis. First, a number of retirement related measures are considered, including full and partial retirement, as well as flows among retirement states, including returns from states of lesser to greater work. Here retirement status is classified based on hours and weeks of employment, but for those who are not working, retirement status is also based on self-reports. We consider differences between reported retirement status and actual employment, and other relevant outcomes for near retirees. We also examine levels and flows in related labor market outcomes, including full-time and parttime work status, losses in job tenure, layoffs, unemployment, unemployment duration, and disability status. In addition to considering the course of each of these outcomes, the relations among these outcomes are analyzed, including the relation of layoffs and unemployment to reported retirement state.

Key outcomes are also compared between the cohort affected by the Great Recession and members of older cohorts when they were the same age. This allows us to distinguish the effects

\footnotetext{
${ }^{1}$ For an earlier study of the relation of layoffs to retirement, see Chan and Stevens (2001). For a study that takes account of demand differences among areas, see Maestas, Mullen and Powell (2013).
} 
of the Great Recession from trends that may have caused differences between cohorts even in the absence of the recession. For example, differences in retirement outcomes between cohorts of women will partially reflect well known trends in their employment patterns. Similarly, trends have been observed in the retirement behavior of men. Studies have attributed these trends to changes in pension and Social Security rules, demographic factors like increasing life expectancy and improved health, the effects of increased participation of wives on the retirement of their husbands, and to other factors. ${ }^{2}$

One interesting issue affecting some measures of retirement and labor market activity is the relation between the Great Recession and perceived retirement status. A key measure is the number of those without a job who nevertheless report themselves as not retired or partially retired. We investigate the relation of perceived retirement status to layoffs and unemployment.

We then turn to a multivariate analysis which focuses on layoffs, unemployment, duration until full-time work is again secured, and the relation of layoffs and unemployment to wages.

Our analysis does not focus on those who were older than the Social Security age of eligibility when the Great Recession began (e.g., see Rutledge, 2013). We are interested in isolating the effects of the Great Recession on those in their fifties who had not yet been subject to strong, immediate incentives from pensions or Social Security. These incentives have changed over time and would make comparisons between cohorts more problematic for isolating the effects of the Great Recession. ${ }^{3}$

\footnotetext{
${ }^{2}$ For an estimate of the importance of each of these factors in determining retirement, as well as a summary of the relevant literature, see Council of Economic Advisors (2014). Gustman and Steinmeier $(2000,2014)$ analyze the relation between the retirement decisions of husbands and wives.

${ }^{3}$ See Anderson, Gustman and Steinmeier (1999) and Gustman and Steinmeier (2009) for analyses of how changes in retirement programs have affected retirement trends.
} 
Section II examines the levels and differences in retirement outcomes experienced over the course of the Great Recession and its recovery by members of the HRS Early Boomer cohort, those 53 to 58 in 2006. Section III compares the retirement flows for the HRS Early Boomers with flows observed for members of older cohorts when they were the same age, introduces other labor market outcomes and compares those outcomes among cohorts at the same age. Section IV explores the relation of unemployment and layoffs to retirement status. Section $\mathrm{V}$ pools those members of all cohorts who were at full-time work in the base period, analyzes changes in unemployment incidence and duration induced by the Great Recession, and explores resulting wage changes. Section VI concludes.

II: Retirement Flows Experienced by Early Boomers Over the Course of the Great Recession In this section our analysis is based on the Early Boomer cohort of the Health and Retirement Study. This cohort was ages 51 to 56 in 2004. They are sampled every two years. The Early Boomers were nearing retirement when they were exposed to the Great Recession (they were 53 to 58 in 2006 before the recession hit). ${ }^{4}$ Their experience over the next six years includes both the periods of decline and recovery from the Great Recession. As of the writing of this paper, 2012 is the last year HRS data are available to us.

We calculate retirement status based on the number of hours and weeks worked per year and, in ambiguous cases, by self-reported retirement status as well. Respondents working at least 30 hours per week and 1560 hours or more per year are classified as not retired. Respondents working less than 100 hours per year are classified as not working. Those working at least 100 hours per year and 25 hours or less per week, or 1250 hours or less per year, are partially retired.

\footnotetext{
${ }^{4}$ We take the onset of the Great Recession to be October, 2007, when the Dow Jones Industrial Average peaked at 14,164. Eighteen months later, on April 15, 2009, it was just below 8,000, a decline of 43 percent. Over the next sixth months, as of September 14, 2009, it had recovered to above 9,500 , leaving a decline from its peak of one third.
} 
If the number of hours per year worked is between 1250 and 1560, but the self-reported retirement status is either retired or not relevant, a partially retired status is assigned to the respondent. Respondents who report between 1250 and 1560 hours worked, but report not retired to the self-reported retirement status question, are considered to be not retired. Those who report they are not working in response to the working for pay question, and report they are not retired or partially retired in response to the retirement status question, are considered to be Not Retired or Partially Retired and Not Working. If they report they are not working, and also report themselves as retired, they are considered to be retired. If they report "not working" and in answer to the self-reported retirement status question answer "not relevant", they are assigned to the "not relevant" category. ${ }^{5}$

We describe the dynamics of retirement for the Early Boomers in Table 1. The row heads indicate retirement status in the base year, 2006, and the column heads show retirement status in 2012.

Looking down the last column of Table 1, in 200662 percent of the Early Boomer cohort was not retired; 10 percent was partially retired and 11 percent fully retired. Of the remainder, 17 percent fall in the "other, not working" category. Among this group, 6 percent indicated that the retirement status question was not relevant. Three percent reported they were partially retired but were not working. Eight percent reported they were not retired but not working. Presumably if a suitable job came along at an acceptable wage, or if sufficient need arose, those who were not retired but not working could see themselves going back to work.

\footnotetext{
${ }^{5}$ The self-reported status question in 1994 to 1998 is different from that question in 1992 and from 2000 forward. The difference is in the definition of "Not relevant" response. From 1994 to 1998 it is defined as "Question not relevant to R, Does not work for pay or is homemaker, has not worked for 1 or more years". In 1992, the response is the same as in 1994 to 1998, except it is noted the number of years "not worked for 10 or more years" instead of "not worked for 1 or more years". From 2000 forward the response is modified to "Question not relevant to R, Does not work for pay or is homemaker, etc.".
} 
Comparing the bottom row of Table 1 with the right hand column, the fraction who were not retired declined by 22 percent over the six year period, the fraction partially retired increased by 1 percent, and the fraction completely retired increased by 21 percent. The other, not working category increased by one percent.

The remaining cells in the matrix provide additional information about changes in work status by individuals. Looking across each row, one can see the change in status conditional on the initial state in 2006. In row 1 the initial state is not retired. From row 1, among those who were not retired in 2006, 58 percent remained in that state, 9 percent partially retired and 22 percent fully retired. Altogether, 31 percent experienced transitions consistent with a move from greater to lesser work. The remaining 11 percent moved into the other not working category.

The next row shows the same flows for those who were initially partially retired in 2006. Proceeding across row 2, we see the first reversal from a state of lesser to greater work, with 19 percent of those who were partially retired in 2006 returning to a state of not retired in 2012. Thirty six percent of those who were partially retired in 2006 remained partially retired in 2012, while twenty seven percent moved from a state of partial to full retirement.

Row 3 reports outcomes in 2012 for those who were fully retired in 2006. Here we find much weaker evidence of reversals. Among those who were fully retired in 2006, 3 percent were not retired in 2012 and 5 percent were partially retired in 2012. Most, 82 percent, remained fully retired in 2012. Lastly, 10 percent of those completely retired in 2006 were classified as other not working in 2012. Results for those who were in the other not working category in 2006 are reported in the following row.

Findings for men and women are presented in Appendix Tables 1 and 2. Comparing retirement status in the base period, we find that women are much less likely to be not retired in the base period than men. The percentages of men in the base period who are not retired, 
partially retired, fully retired and other not working are 71, 6, 11 and 11 percent respectively. For women, the corresponding percentages are 54, 13, 11 and 22.

\section{Retirement Outcomes}

Table 1: Retirement Flows from 2006 to 2012 for Early Boomers: Ages 53-58 in 2006. All (weighted)

\begin{tabular}{|l|c|c|c|c|c||}
\hline \multirow{2}{*}{ Status in 2006} & \multicolumn{3}{|c|}{ Status in 2012 } & \\
\cline { 2 - 6 } & Not Retired & $\begin{array}{l}\text { Partially } \\
\text { Retired } \\
\text { Completely } \\
\text { Retired } \\
\text { Other Not } \\
\text { Working }\end{array}$ & $\begin{array}{l}\text { Row Total } \\
\text { Status in } \\
2006\end{array}$ \\
\hline \hline Not Retired & 58 & 9 & 22 & 11 & 62 \\
\hline Partially Retired & 19 & 36 & 27 & 17 & 11 \\
\hline Completely Retired & 3 & 5 & 82 & 10 & 10 \\
\hline Other Not Working* & 11 & 8 & 44 & 37 & 16 \\
\hline $\begin{array}{l}\text { Column Total } \\
\text { (Status in 2012) }\end{array}$ & 40 & 11 & 32 & & 10 \\
\hline
\end{tabular}

*Other Not Working category includes respondents who were not working and reported not retired or partially retired and those who reported "Not Relevant" when they were asked about their retirement status. The number of years required to answer "Not Relevant" varies between survey years. 
The flows into various retirement states in 2012, conditional on being Not Retired in 2006, are not very different between men and women. That also is true for those beginning in other retirement states.

The differences in retirement outcomes between men and women in 2012 are largely the result of differences in initial status in 2006, rather than to differences in retirement flows conditional on initial retirement state.

Next we consider the differences in retirement flows between the period of deepening recession, 2008 to 2010, and the initial period of recovery, 2010 to 2012 . We focus on the Early Boomers. For consistency in comparisons, the sample includes those respondents who were included in the survey in 2008, 2010 and 2012.

Table 2 shows the flow from 2008 to 2010, while Table 3 shows the flow from 2010 to 2012. As would be expected, the values in the bottom row of Table 2 match the values in the right hand column of Table 3. Comparing the last column of Table 2 with the bottom row of that table, between 2008 and 2010, the fraction of the sample "Not Retired" declined by 10 percentage points, while the fraction "Completely Retired" increased by 7 percentage points. Although the population is two years older in Table 3, the share "Not Retired" declined by only 7 percentage points between 2010 and 2012, while the fraction "Completely Retired" increased by 10 percentage points. 
Table 2: Retirement Flows from 2008 to 2010 for Early Boomers*: Ages 55-60 in 2008. All (weighted)

\begin{tabular}{|l|c|c|c|c|c||}
\hline \multirow{2}{*}{ Status in 2008 } & \multicolumn{4}{|c||}{ Status in 2010 } & \multirow{2}{*}{ Row Total } \\
\cline { 2 - 6 } & Not Retired & $\begin{array}{l}\text { Partially } \\
\text { Retired } \\
\text { Completely } \\
\text { Retired }\end{array}$ & $\begin{array}{l}\text { Other Not } \\
\text { Working }\end{array}$ & $\begin{array}{l}\text { Status in } \\
2008\end{array}$ \\
\hline Not Retired & 78 & 6 & 6 & 10 & 62 \\
\hline Partially Retired & 18 & 59 & 10 & 13 & 11 \\
\hline Completely Retired & 1 & 4 & 83 & 12 & 16 \\
\hline Other Not Working & 9 & 11 & 25 & 55 & 17 \\
\hline $\begin{array}{l}\text { Column Total } \\
\text { (Status in 2010) }\end{array}$ & 52 & 12 & 19 & & 100 \\
\hline
\end{tabular}

*The sample (2540 cases) is restricted to those who were present in the survey waves of 2008, 2010, and 2012. The weight is from 2010.

Table 3: Retirement Flows from 2010 to 2012 for Early Boomers*: Ages 57-62 in 2010. All (weighted)

\begin{tabular}{|c|c|c|c|c|c|}
\hline \multirow[b]{2}{*}{ Status in 2010} & \multicolumn{4}{|c|}{ Status in 2012} & \multirow[b]{2}{*}{$\begin{array}{l}\text { Row Total } \\
\text { Status in } \\
2010\end{array}$} \\
\hline & Not Retired & $\begin{array}{l}\text { Partially } \\
\text { Retired }\end{array}$ & $\begin{array}{l}\text { Completely } \\
\text { Retired }\end{array}$ & $\begin{array}{l}\text { Other Not } \\
\text { Working }\end{array}$ & \\
\hline Not Retired & 79 & 5 & 9 & 7 & 52 \\
\hline Partially Retired & 13 & 52 & 17 & 17 & 12 \\
\hline Completely Retired & 0 & 3 & 88 & 8 & 19 \\
\hline Other Not Working & 10 & 11 & 34 & 45 & 17 \\
\hline $\begin{array}{l}\text { Column Total } \\
\text { (Status in 2012) }\end{array}$ & 45 & 11 & 29 & 15 & 100 \\
\hline
\end{tabular}

*The sample (2540 cases) is restricted to those who were present in the survey waves of 2008, 2010, and 2012. The weight is from 2010. 


\section{Cohort Differences in Retirement and Other Labor Market Outcomes}

The first four rows of Table 4, last two columns, repeat the levels of retirement outcomes observed in 2008 and 2010 for Early Boomers. ${ }^{6}$ Columns 1 to 4 of Table 4 report the outcomes for members of older cohorts at the same age. Comparing values in columns 1, 3 and 5 for retirement outcomes listed in the first four rows of the table, one can see a slight increase in the percent not retired over time, as well as a decline in the fraction cohort falling in the other not working category. ${ }^{7}$ Comparing columns 2,4 and 6 in these first four rows, which report values for the end year of each two year period, there are no obvious changes for the Early Boomers associated with the Great Recession.

The remaining rows of the table provide a first look at how the Great Recession affected layoffs, unemployment, long term job attachment, and related outcomes. From row 5, columns 1, 3 and 5, there is a slight upward trend in the fraction of cohorts working 35 hours or more per year. Since hours of work is one component of our retirement status measure in row 1, the results in rows 1 and 5 show similar trends. Looking at columns 2, 4 and 6 of rows 1 and 5, there are no trends at all in these outcomes. That is, the level of retirement or full-time work in the second year of the two year period is similar among cohorts.

\footnotetext{
${ }^{6}$ The difference in outcomes between Tables 2 and 4 is the result of restricting the sample in Table 2 to those with observations in 2008, 2010 and 2012. In Table 4, the sample includes respondents who had observations in 2008 and 2010.

${ }^{7}$ Underlying the change in the "Other Not Working" category is a major difference among cohorts in the fraction reporting their retirement status as "Not Relevant". Nine percent of the War Babies fell in the Not Relevant category in 2004. The status of members of the original HRS cohort was listed as Not Relevant in 16 percent of the cases in 1998. And in the Early Boomer category, 4 percent of the respondents fell in the Not Relevant category in 2010. The changing fraction of a cohort for whom retirement status is not relevant is both the result of retirement trends, and also is an artifact of changes in the HRS retirement questions over the years of the survey. Specifically, in the early waves of the HRS survey a longer period of previous work was required before the retirement question was classified as relevant.
} 
When compared to older cohorts, there are increases for Early Boomers in the percent reporting unemployment or layoffs, and these appear to be associated with the Great Recession. But despite an increase in layoffs, changes in long term employment are similar to those observed over more stable periods.

Also noteworthy in the table is the trend in participation in Social Security disability insurance. Any change in SSDI participation associated with the Great Recession appears to be obscured by a much stronger trend measured among cohorts.

While Table 4 shows levels and changes in key labor market outcomes over a two year period corresponding to the onset of the Great Recession, and experiences during comparison years for members of older cohorts, Table 5 indicates these same outcomes at the beginning and end of the six year period spanning the Great Recession. In the base year, respondents range between ages 53 and 58. For the Early Boomers, the six year period spans a time ranging from just before the onset of the Great Recession, 2006, through the latest HRS data available relating to the recovery, in 2012.

Looking at the base years in columns 1,3 and 5 , for the most part there are no noteworthy trends. An exception is the increase in SSDI participation (applied or receiving benefits) from 2 percent to 6 percent of the sample. Comparing columns 2, 4 and 6, there also are noticeable changes in the levels observed for the end years of each six year period. The fraction completely retired rises over time, while other not working declines. The change in fraction on DI between the initial and end date is similar for each cohort, however, so that once again we perceive no extraordinary effect of the Great Recession on DI participation.

There are no obvious trends in the fraction working more than 35 hours, long term employed, or in layoffs. 
Table 4: Levels of Retirement, Unemployment and Related Outcomes Over Two Years of Downturn from Great Recession for those Ages 55 to 60 in 2008 and Over Comparable Ages for Members of Older Cohorts

\begin{tabular}{|c|c|c|c|c|c|c|}
\hline & $\begin{array}{c}\text { Original } \\
\text { HRS } \\
1996\end{array}$ & $\begin{array}{c}\text { Original } \\
\text { HRS } 1998\end{array}$ & $\begin{array}{c}\text { War- } \\
\text { babies } \\
2002\end{array}$ & $\begin{array}{c}\text { War- } \\
\text { babies } \\
2004\end{array}$ & $\begin{array}{c}\text { Early } \\
\text { Boomers } \\
2008\end{array}$ & $\begin{array}{c}\text { Early } \\
\text { Boomers } \\
2010\end{array}$ \\
\hline \multicolumn{7}{|c|}{ Individual's Retirement Status } \\
\hline 1- Percent not retired & 56 & 50 & 58 & 51 & 59 & 50 \\
\hline 2- Percent partially retired & 10 & 11 & 9 & 11 & 10 & 11 \\
\hline 3- Percent completely retired & 13 & 15 & 13 & 19 & 13 & 20 \\
\hline 4- Other not working & 21 & 23 & 20 & 19 & 17 & 19 \\
\hline $\begin{array}{l}\text { 5- Percent working more than } 35 \text { hours } \\
\text { per week }\end{array}$ & 51 & 46 & 53 & 47 & 55 & 46 \\
\hline 6 - Percent $10+$ to $12+$ years on the job & 33 & 26 & 33 & 27 & 33 & 27 \\
\hline 7- Percent reporting layoff & 5 & 6 & 7 & 4 & 4 & 8 \\
\hline 8- Percent unemployed & 3 & 2 & 3 & 2 & 4 & 6 \\
\hline 9- Percent taking window plan & 2 & 2 & 1 & 1 & 1 & 1 \\
\hline 10- Percent on SSDI & 3 & 3 & 6 & 7 & 7 & 9 \\
\hline
\end{tabular}


Table 5: Levels of Retirement, Unemployment and Related Outcomes Over Six Year Period Spanning Great Recession and Recovery for those age 53 to 58 in 2006 and Over Comparable Ages for Members of Older Cohorts

\begin{tabular}{|c|c|c|c|c|c|c|}
\hline & $\begin{array}{c}\text { Original } \\
\text { HRS } \\
1994\end{array}$ & $\begin{array}{c}\text { Original } \\
\text { HRS } 2000\end{array}$ & $\begin{array}{c}\text { War- } \\
\text { babies } \\
2000\end{array}$ & $\begin{array}{c}\text { War- } \\
\text { babies } \\
2006\end{array}$ & $\begin{array}{c}\text { Early } \\
\text { Boomers } \\
2006\end{array}$ & $\begin{array}{c}\text { Early } \\
\text { Boomers } \\
2012\end{array}$ \\
\hline \multicolumn{7}{|c|}{ Individual's Retirement Status } \\
\hline 1- Percent not retired & 63 & 42 & 65 & 43 & 62 & 40 \\
\hline 2- Percent partially retired & 9 & 12 & 10 & 13 & 10 & 11 \\
\hline 3- Percent completely retired & 10 & 23 & 8 & 28 & 11 & 32 \\
\hline 4- Other not working & 18 & 23 & 18 & 17 & 17 & 15 \\
\hline $\begin{array}{l}\text { 5- Percent working more than } 35 \\
\text { hours per week }\end{array}$ & 56 & 38 & 61 & 39 & 57 & 37 \\
\hline $\begin{array}{l}6 \text { - Percent } 10+\text { to } 12+\text { years on the } \\
\text { job }\end{array}$ & 36 & 18 & 39 & 20 & 35 & 18 \\
\hline 7- Percent reporting layoff & 6 & 4 & 4 & 3 & 3 & 4 \\
\hline 8- Percent unemployed & 3 & 1 & 1 & 1 & 3 & 3 \\
\hline 9- Percent taking window plan & 1 & 1 & 1 & 0 & 0 & 1 \\
\hline 10- Percent on SSDI & 2 & 6 & 4 & 9 & 6 & 11 \\
\hline
\end{tabular}

Sample includes those who were interviewed in the base and end year, and also in the waves in between. 
We now focus directly on the changes in these outcomes over the two and six year periods, rather than the levels of outcomes. From Table 6 we see that over the first two years of the Great Recession, the change in the frequency of Early Boomer respondents reporting they were Not Retired was -9 percentage points, which is two to three percentage points greater, in absolute terms, than the decline experienced over the same age span by members of older cohorts.

In row 5, we see a three percentage point difference between Early Boomers and members of older cohorts in the percent reducing work over the two year period. Focusing directly on the fraction working 35 hours in row 8 , this measure declined by 9 percentage points for Early Boomers, which is a 3 or 4 percentage point greater decline than was observed for members of older cohorts at the same age. In contrast to the measure of full-time work, there was little difference in row 9 between cohorts in the change in the percentage on a long term job.

Moving to Table 7, we examine these same changes for the six years spanning the Great Recession for the Early Boomers, and over comparable ages for the members of the other two cohorts. From rows 5 and 6 , there are no differences in the percentage reducing work among cohorts, nor in the percentages working the same amount. 
Table 6: Measures of Differences in Retirement, Unemployment and Related Outcomes over Two Year Period: Ages 55 to 60 in 1996, 2002, and 2008. (weighted)

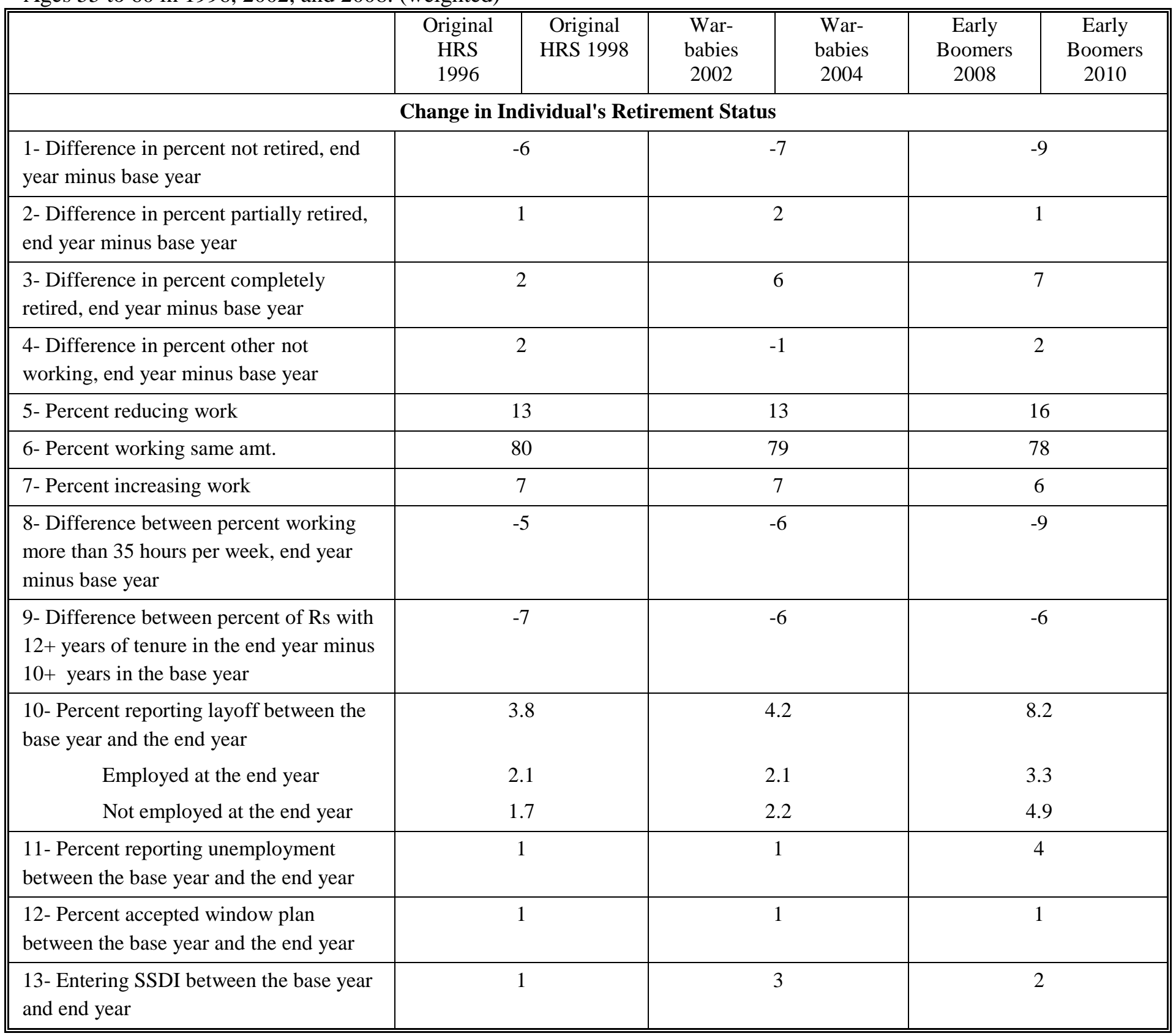


Table 7: Measures of Differences in Retirement, Unemployment and Related Outcomes Over Six Year Period: Ages 53 to 58 in the base year. (weighted)

\begin{tabular}{|c|c|c|c|c|c|c|}
\hline & $\begin{array}{l}\text { Original } \\
\text { HRS } \\
1994\end{array}$ & $\begin{array}{l}\text { Original } \\
\text { HRS } 2000\end{array}$ & $\begin{array}{l}\text { War- } \\
\text { babies } \\
2000\end{array}$ & $\begin{array}{c}\text { War- } \\
\text { babies } \\
2006\end{array}$ & $\begin{array}{l}\text { Early } \\
\text { Boomers } \\
2006\end{array}$ & $\begin{array}{l}\text { Early } \\
\text { Boomers } \\
2012\end{array}$ \\
\hline \multicolumn{7}{|c|}{ Change in Individual's Retirement Status } \\
\hline $\begin{array}{l}\text { 1- Difference in Percent not retired, } \\
\text { end year minus base year }\end{array}$ & \multicolumn{2}{|r|}{-21} & \multicolumn{2}{|c|}{-22} & \multicolumn{2}{|r|}{-22} \\
\hline $\begin{array}{l}\text { 2- Difference in Percent partially } \\
\text { retired, end year minus base year }\end{array}$ & \multicolumn{2}{|r|}{3} & \multicolumn{2}{|c|}{3} & \multicolumn{2}{|r|}{1} \\
\hline $\begin{array}{l}\text { 3- Difference in Percent completely } \\
\text { retired, end year minus base year }\end{array}$ & \multicolumn{2}{|r|}{13} & \multicolumn{2}{|c|}{20} & \multicolumn{2}{|r|}{21} \\
\hline $\begin{array}{l}\text { 4- Difference in percent other not } \\
\text { working, end year minus base year }\end{array}$ & \multicolumn{2}{|r|}{5} & \multicolumn{2}{|c|}{-1} & \multicolumn{2}{|r|}{-2} \\
\hline 5- Percent reducing work & \multicolumn{2}{|r|}{29} & \multicolumn{2}{|c|}{30} & \multicolumn{2}{|r|}{30} \\
\hline 6- Percent working same amt. & \multicolumn{2}{|r|}{64} & \multicolumn{2}{|c|}{63} & \multicolumn{2}{|r|}{64} \\
\hline 7- Percent increasing work & \multicolumn{2}{|r|}{7} & \multicolumn{2}{|c|}{6} & \multicolumn{2}{|r|}{6} \\
\hline $\begin{array}{l}\text { 8- Difference between Percent } \\
\text { working more than } 35 \text { hours per week, } \\
\text { end year minus base year }\end{array}$ & \multicolumn{2}{|r|}{-18} & \multicolumn{2}{|c|}{-22} & \multicolumn{2}{|r|}{-20} \\
\hline $\begin{array}{l}\text { 9- Difference between Percent of Rs } \\
\text { who had } 16+\text { years of tenure in the } \\
\text { end year minus those with } 10+\text { years } \\
\text { in the base year }\end{array}$ & \multicolumn{2}{|r|}{-18} & \multicolumn{2}{|c|}{-19} & \multicolumn{2}{|r|}{-17} \\
\hline $\begin{array}{l}\text { 10- Percent reporting layoff any time } \\
\text { in } 6 \text { year period }\end{array}$ & \multicolumn{2}{|r|}{11} & \multicolumn{2}{|c|}{11} & \multicolumn{2}{|r|}{14} \\
\hline $\begin{array}{l}\text { 11- Percent reporting unemployment } \\
\text { any time in the } 6 \text { year period }\end{array}$ & \multicolumn{2}{|r|}{4} & \multicolumn{2}{|c|}{4} & \multicolumn{2}{|r|}{8} \\
\hline $\begin{array}{l}\text { 12- Percent accepted window plan any } \\
\text { time in } 6 \text { year period }\end{array}$ & \multicolumn{2}{|r|}{4} & \multicolumn{2}{|c|}{3} & \multicolumn{2}{|r|}{3} \\
\hline $\begin{array}{l}\text { 13- Entering SSDI between the base } \\
\text { year and end year }\end{array}$ & \multicolumn{2}{|r|}{4} & & & & 6 \\
\hline
\end{tabular}

Sample includes those who were interviewed in the base and end year, and also in the waves in between. 
Layoffs and Unemployment Induced by the Great Recession Relative to Older Cohorts:

We also have calculated the fraction of the population experiencing layoffs and unemployment. In Table 6, line 10, over the two year period corresponding to the onset of the Great Recession, 2008 to 2010, layoffs were experienced by 8.2 percent of the Early Boomers, compared to 4 percent of members from the older cohorts over the same age span. Thus the share of the population experiencing a layoff was about four percentage points higher during the period of the Great Recession. Most of this difference reflects layoffs that did not end with reemployment. ${ }^{8}$ From line 11, unemployment experienced by Early Boomers over the 2008-10 period is 3 percentage points greater than unemployment experienced by those in older cohorts when they were the same age. ${ }^{9}$

Table 7 considers layoffs and unemployment by Early Boomers over the six year period spanning the Great Recession, and compares that experience to the experience of members of older cohorts when they were the same age. While from line 11, 4 percent of the members of older cohorts experienced unemployment any time over the six year period, 8 percent of Early Boomers experienced unemployment. And from line 10, while 11 percent of the members of older cohorts experienced a layoff any time over the six year period, 14 percent of Early Boomers experienced a layoff.

\footnotetext{
${ }^{8}$ To identify involuntary layoffs, we consider first those who were working in the previous interview wave of the survey but reported not working in the current wave. For those who were working in the current wave we inquire whether they were working in the same job they held in the wave two years earlier. If not, we look at the question as to the reason they left the job they had held two years earlier. If the reason included such things as "business closed" or "laid off/let go," or "would have been laid off", the response is coded as an involuntary termination. Layoff is from respondent's previous job.

${ }^{9}$ In a table that is not included, we find the layoff rate between 1998 and 2000 for the HRS cohort, ages 57 to 62 in 1998, to be 3.52 and the percent who are unemployed in 2000 who were employed in 1998 is 0.78 . For WBs (the same age group in 2004) the layoff rate between 2004 and 2006 is 2.63 and the percent unemployed who were employed in 2004 is 0.64 . For EBs (the same age group in 2010) the layoff rate between 2010 and 2012 is 4.56 and the corresponding percent unemployed who were employed in the previous wave is 2.27 .
} 
It appears that additional layoffs induced by the Great Recession explain the actual change in employment fairly well. In Table 6 , the percent reporting a layoff between the base year and the end year who were not employed at the end year rose from $(1 / 2)(1.7+2.2)=1.45$ (the average of the HRS and War Babies) to 4.9 (Early Boomers). That is, unemployment from layoffs increased by 3.45 percentage points for the Early Boomers during Great Recession period. Meanwhile, the percentage employed (difference in percent not retired plus difference in percent partially retired) changed from -5 percent for the HRS cohort and War Babies to -8 percent for the Early Boomers, declining an additional 3 percentage points in the Great Recession. That is, the reduction in employment for the Early Boomers was 3 percentage points greater in absolute terms than for the other cohorts, and this approximately matches the 3.5 percentage point increase in layoffs with no reemployment for the Early Boomers.

In Appendix Tables 3 we restricted the sample to those who were working full-time in the base year. The rate at which respondents leave the state of Not Retired is almost twice as high among full-time workers in Appendix Table 3 as it is for the age 53 to 58 population as a whole in Table 7. But there are no apparent trends in retirement among the cohorts. The difference in the percent reporting a layoff increases from 3 percentage points for the full sample to 5 or 6 percentage points among full-time workers.

When in Appendix Table 4 we limit the sample to full-time workers with at least ten years of tenure in the base period, layoffs over the period of the Great Recession are 4 to 5 percentage points higher than layoffs in earlier periods for members of older cohorts over the same age span.

IV: Relationship of Layoffs to Not Retired/Partially Retired and Not Working

Next we investigate the relation of a respondent having been laid off to the respondent reporting they are not working but also not retired or partially retired. Table 8 reports the number 
of respondents with these outcomes in 2008 and 2010 for Early Boomers, and in years when members of older cohorts were comparable ages. As seen in row 1, apparently as a result of the Great Recession, there is a sharp jump in the number of Early Boomers who have been laid off and who are Not Retired or Partially Retired, and Not Working. The number of respondents in this category more than doubles between 2008 and 2010, from 52 to 116.

From row 4, column 6, in 2010, those who experienced a layoff account for about one quarter of those who are Not Retired or Partially Retired and Not Working. This is 5 to 11 percentage points higher than similar ratios observed for older cohorts in columns 2 and 4.

From row 5, which compares rows 1 and 3, in 2010 only about half of those who experienced a layoff report themselves as Not Retired or Partially Retired, Not Working. This is substantially higher than the values found for older cohorts, where one quarter to one third of those who experienced a layoff reported they were also Not Retired or Partially Retired and Not Working.

Those who were involuntarily laid off may be reluctant to declare themselves as permanently out of the labor force. Some may be responding to asset losses from the Great Recession. ${ }^{10}$ Others may claim they are not yet retired in reaction to increased uncertainty. Still others who did not lose their jobs, some in positions where they have accumulated considerable tenure, may defer retiring or leaving their main job in reaction to wealth loss or increased uncertainty.

The bottom line here is that even when the Great Recession had its peak effects, only half of those who experienced a layoff ended up in the Not Retired or Partially Retired, Not Working category, and only a quarter of those who are Not Retired or Partially Retired, Not Working, have experienced a layoff. Most of the jump in Not Retired or Partially Retired, Not Working

\footnotetext{
${ }^{10}$ For documentation of wealth loss over the period of the Great Recession, see Gustman, Steinmeier and Tabatabai (2014).
} 
associated with the Great Recession appears to reflect a change in expectations about the potential for future work, or a change in assets, neither of which is the result of job loss.

Table 9 reports analogous results to those reported in Table 8, but the sample is restricted to those who worked full-time in the base year. The layoff rate was higher for full-time workers than for the full sample, with $8.4 \%$ (229/2736) of the full sample having been laid off by 2010, and $11.5 \%$ (176/1534) of those who were full-time workers in 2008 having been laid off by 2010. Fifty seven percent of Not Retired or Partially Retired, Not Working among full-time workers are accounted for by those who experienced a layoff. Fifty two percent of those who experienced a layoff among full-time workers reported themselves as Not Retired or Partially Retired, and Not Working. These numbers are much higher than those experienced by members of older cohorts at comparable ages, where these ratios are roughly one third.

Table 10 reports comparable results to those in Tables 8, using unemployment status instead of layoffs. In 2010, about 17 percent (460/2736) of the population is Not Retired or Partially Retired and Not Working. Six percent of the population (164/2736) is unemployed. That leaves roughly 9 percent of the population Not Retired or Partially Retired and Not Working, but not unemployed. 
Table 8: Relationship of Layoffs to the Frequency of Reporting Oneself as Not Retired/Partially Retired Not Working, Ages 55 to 60 in the Base Year.

\begin{tabular}{|c|c|c|c|c|c|c|}
\hline & \multicolumn{2}{|c|}{ Original HRS } & \multicolumn{2}{|c|}{ War-babies } & \multicolumn{2}{|c|}{ Early Boomers } \\
\hline & 1996 & 1998 & 2002 & 2004 & 2008 & 2010 \\
\hline $\begin{array}{l}\text { 1-Laid Off and Not Retired or } \\
\text { partially retired- Not Working } \\
\text { in Indicated Year }\end{array}$ & 62 & 66 & 59 & 40 & 52 & 116 \\
\hline $\begin{array}{l}\text { 2-Total Not Retired or } \\
\text { partially retired- Not Working } \\
\text { in Indicated Year }\end{array}$ & 395 & 322 & 285 & 282 & 308 & 460 \\
\hline $\begin{array}{l}\text { 3- Total Layoffs in Indicated } \\
\text { Year }\end{array}$ & 218 & 251 & 167 & 124 & 125 & 229 \\
\hline $\begin{array}{l}\text { 4-Percentage of Those Not } \\
\text { Retired or partially retired - } \\
\text { Not Working Who } \\
\text { Experienced a Layoff } \\
\text { Between Last Wave and } \\
\text { Current Wave }\end{array}$ & $\begin{array}{c}62 / 395= \\
16 \%\end{array}$ & $\begin{array}{c}66 / 322= \\
20 \%\end{array}$ & $\begin{array}{c}59 / 285= \\
21 \%\end{array}$ & $\begin{array}{c}40 / 282= \\
14 \%\end{array}$ & $\begin{array}{c}52 / 308= \\
17 \%\end{array}$ & $\begin{array}{c}116 / 460= \\
25 \%\end{array}$ \\
\hline $\begin{array}{l}\text { 5-Percentage of Those Who } \\
\text { Experienced a Layoff Who } \\
\text { Are Also Not Retired- Not } \\
\text { Working }\end{array}$ & $\begin{array}{c}62 / 218= \\
28 \%\end{array}$ & $\begin{array}{c}66 / 251= \\
26 \%\end{array}$ & $\begin{array}{c}59 / 167= \\
35 \%\end{array}$ & $\begin{array}{c}40 / 124= \\
32 \%\end{array}$ & $\begin{array}{c}52 / 125= \\
42 \%\end{array}$ & $\begin{array}{c}116 / 229= \\
51 \%\end{array}$ \\
\hline Number of observations & \multicolumn{2}{|c|}{4410} & \multicolumn{2}{|c|}{2706} & \multicolumn{2}{|c|}{2736} \\
\hline
\end{tabular}


Table 9: Relationship of Layoffs to the Frequency of Reporting Oneself as Not Retired/Partially Retired Not Working, Ages 55 to 60 and Fulltime in the Base Year.

\begin{tabular}{|c|c|c|c|c|c|c|}
\hline & \multicolumn{2}{|c|}{ Original HRS } & \multicolumn{2}{|c|}{ War-babies } & \multicolumn{2}{|c|}{ Early Boomers } \\
\hline & 1996 & 1998 & 2002 & 2004 & 2008 & 2010 \\
\hline $\begin{array}{l}\text { 1-Laid Off and Not Retired or } \\
\text { partially retired- Not Working } \\
\text { in Indicated Year }\end{array}$ & - & 37 & - & 29 & - & 100 \\
\hline $\begin{array}{l}\text { 2-Total Not Retired or Partially } \\
\text { Retired- Not Working in } \\
\text { Indicated Year }\end{array}$ & - & 111 & - & 86 & - & 176 \\
\hline $\begin{array}{l}\text { 3- Total Layoffs in Indicated } \\
\text { Year }\end{array}$ & - & 128 & - & 90 & - & 192 \\
\hline $\begin{array}{l}\text { 4-Percentage of Those Not } \\
\text { Retired or Partially Retired - } \\
\text { Not Working Who Experienced } \\
\text { a Layoff Between Last Wave } \\
\text { and Current Wave }\end{array}$ & - & $\begin{array}{c}37 / 111= \\
33 \%\end{array}$ & - & $\begin{array}{c}29 / 86= \\
34 \%\end{array}$ & - & $\begin{array}{c}100 / 176= \\
57 \%\end{array}$ \\
\hline $\begin{array}{l}\text { 5-Percentage of Those Who } \\
\text { Experienced a Layoff Who Are } \\
\text { Also Not Retired- Not Working }\end{array}$ & - & $\begin{array}{c}37 / 128= \\
29 \%\end{array}$ & - & $\begin{array}{c}29 / 90= \\
32 \%\end{array}$ & - & $\begin{array}{c}100 / 192= \\
52 \%\end{array}$ \\
\hline Number of observations & \multicolumn{2}{|c|}{2323} & \multicolumn{2}{|c|}{1405} & \multicolumn{2}{|c|}{1534} \\
\hline
\end{tabular}


From the last two columns of Table 10, rows 1 and 2, while the number unemployed and Not Retired or Partially Retired and Not Working grew by $63(150-87)$ between 2008 and 2010, the total Not Retired or Partially Retired and Not Working grew by 152 (460 - 308). Once again, the growth in the ranks of the Not Retired and Not Partially Retired consists only in part of the newly unemployed, the same result we found for layoffs. From the last column, row 4, about one third of those who reported themselves as Not Retired or Partially Retired and Not Working experienced unemployment between the last wave and the current wave. This is up 5 percentage points from the value in 2008. In contrast, members of older cohorts experienced a 4 to 8 percentage point decline in this ratio between the base year and final year. Once again the Great Recession raised the number Not Retired and Not Partially Retired -Not Working, but by more than twice the increase in the number unemployed.

One difference between Tables 8 and 10 may be noted. The fraction of those who experienced unemployment who reported themselves Not Retired, Not Partially Retired and Not Working, is around 90 percent. This result, shown in row 5 of Table 10, is due to the definition of unemployment. It differs from the comparable finding in Table 8, where only half of those who experienced a layoff reported themselves as Not Retired, Not Partially Retired, and Not Working. 
Table 10: Relationship of Unemployed to the Frequency of Reporting Oneself as Not Retired/Partially Retired - Not Working, Ages 55 to 60 in the Base Year.

\begin{tabular}{|c|c|c|c|c|c|c|}
\hline & \multicolumn{2}{|c|}{ Original HRS } & \multicolumn{2}{|c|}{ War-babies } & \multicolumn{2}{|c|}{ Early Boomers } \\
\hline & 1996 & 1998 & 2002 & 2004 & 2008 & 2010 \\
\hline $\begin{array}{l}\text { 1-Unemployed and Not } \\
\text { Retired or partially retired- } \\
\text { Not Working in Indicated } \\
\text { Year }\end{array}$ & 91 & 61 & 65 & 41 & 87 & 150 \\
\hline $\begin{array}{l}\text { 2-Total Not Retired or } \\
\text { partially retired- Not Working } \\
\text { in Indicated Year }\end{array}$ & 395 & 322 & 285 & 282 & 308 & 460 \\
\hline $\begin{array}{l}\text { 3- Total \# of Unemployed in } \\
\text { Indicated Year }\end{array}$ & 119 & 72 & 75 & 46 & 99 & 164 \\
\hline $\begin{array}{l}\text { 4-Percentage of Those Not } \\
\text { Retired or partially retired - } \\
\text { Not Working Who } \\
\text { Experienced Unemployment } \\
\text { Between Last Wave and } \\
\text { Current Wave }\end{array}$ & $\begin{array}{c}91 / 395= \\
23 \%\end{array}$ & $\begin{array}{c}61 / 322= \\
19 \%\end{array}$ & $\begin{array}{c}65 / 285= \\
23 \%\end{array}$ & $\begin{array}{c}41 / 282= \\
15 \%\end{array}$ & $\begin{array}{c}87 / 308= \\
28 \%\end{array}$ & $\begin{array}{c}150 / 460= \\
33 \%\end{array}$ \\
\hline $\begin{array}{l}\text { 5-Percentage of Those Who } \\
\text { Experienced Unemployment } \\
\text { Who Are Also Not Retired- } \\
\text { Not Working }\end{array}$ & $\begin{array}{c}91 / 119= \\
76 \%\end{array}$ & $\begin{array}{c}61 / 72= \\
85 \%\end{array}$ & $\begin{array}{c}65 / 75= \\
87 \%\end{array}$ & $\begin{array}{c}41 / 46= \\
89 \%\end{array}$ & $\begin{array}{c}87 / 99= \\
88 \%\end{array}$ & $\begin{array}{c}150 / 164= \\
91 \%\end{array}$ \\
\hline Number of observations & \multicolumn{2}{|c|}{4410} & \multicolumn{2}{|c|}{2706} & \multicolumn{2}{|c|}{2736} \\
\hline
\end{tabular}


Table 11: Relationship of Unemployed to the Frequency of Reporting Oneself as Not Retired/Partially Retired - Not Working, Ages 55 to 60 in the Base Year, Working Full-time.

\begin{tabular}{|c|c|c|c|c|c|c|}
\hline & \multicolumn{2}{|c|}{ Original HRS } & \multicolumn{2}{|c|}{ War-babies } & \multicolumn{2}{|c|}{ Early Boomers } \\
\hline & 1996 & 1998 & 2002 & 2004 & 2008 & 2010 \\
\hline $\begin{array}{l}\text { 1-Unemployed and Not } \\
\text { Retired or partially retired- } \\
\text { Not Working in Indicated } \\
\text { Year }\end{array}$ & - & 31 & - & 24 & - & 97 \\
\hline $\begin{array}{l}\text { 2-Total Not Retired or } \\
\text { partially retired- Not Working } \\
\text { in Indicated Year }\end{array}$ & - & 111 & - & 86 & - & 176 \\
\hline $\begin{array}{l}\text { 3- Total \# of Unemployed in } \\
\text { Indicated Year }\end{array}$ & - & 34 & - & 25 & - & $104 *$ \\
\hline $\begin{array}{l}\text { 4-Percentage of Those Not } \\
\text { Retired or partially retired - } \\
\text { Not Working Who } \\
\text { Experienced Unemployment } \\
\text { Between Last Wave and } \\
\text { Current Wave }\end{array}$ & - & $\begin{array}{c}31 / 111= \\
28 \%\end{array}$ & - & $\begin{array}{c}24 / 86= \\
28 \%\end{array}$ & - & $\begin{array}{c}97 / 176= \\
55 \%\end{array}$ \\
\hline $\begin{array}{l}\text { 5-Percentage of Those Who } \\
\text { Experienced Unemployment } \\
\text { Who Are Also Not Retired- } \\
\text { Not Working }\end{array}$ & - & $\begin{array}{c}31 / 34= \\
91 \%\end{array}$ & - & $\begin{array}{c}24 / 25= \\
96 \%\end{array}$ & - & $\begin{array}{c}97 / 104= \\
93 \%\end{array}$ \\
\hline Number of observations & \multicolumn{2}{|c|}{2323} & \multicolumn{2}{|c|}{1405} & \multicolumn{2}{|c|}{1534} \\
\hline
\end{tabular}

* From this sample, 9 cases who reported unemployed and looking for work in the labor force question also reported either working or retired. 
In Table 11 we recalculate the relationship of Not Retired, Not Partially Retired and Not Working to the number Unemployed for those who were working full-time in the base year. Here 55 percent of those who reported themselves as Not Retired or Partially Retired and Not Working experienced unemployment between the last wave and the current wave. Compared to members of older cohorts, the importance of unemployment in accounting for the not working, not retired group doubled with the Great Recession. For those who started in a full-time job, unemployment plays a greater role in explaining the Not Retired or Partially Retired and Not Working group than it does for the overall population.

Nevertheless, even when the Great Recession had its peak effects, only half of those who experienced a layoff ended up in the Not Retired or Partially Retired, Not Working categories, and only a quarter of those who are Not Retired or Partially Retired, Not Working, have experienced a layoff. Most of the jump in Not Retired or Partially Retired, Not Working appears to reflect a change in expectations about the potential for future work, a change that is not the result of job loss.

In a related table (not shown), we also found that the increased layoffs and resulting unemployment resulting from the Great Recession struck lower tenure workers more severely. than higher tenure workers. Most of the individuals experiencing layoffs still regard themselves as not retired, at least for a while, even if they do not find other work.

V. Multivariate Analysis of Layoffs and Unemployment

For the bulk of the population, which has not been laid off, retirement status is measured objectively by the amount of work supplied. However, the descriptive analysis has shown that retirement status and employment status may be quite different for those who have lost their job. For job losers, much of the relation between retirement status and layoffs, or unemployment 
status, is based on respondents' expectations of future work, even though they do not presently have a job.

To avoid having to rely on subjective expectations based on unspecified circumstances, the remainder of our analysis will focus on the relation of the Great Recession to employment, layoffs and unemployment, rather than on a measure of retirement status based on expectations. The analysis is multivariate. Covariates are included to standardize for the effects of job tenure, experience, education, demographic measures, industry, occupation and the individual's wage. Standardizing for these factors, we then look for the average difference in outcomes during the 2008-10 period.

Layoffs

The most important of the effects of the Great Recession on employment is on the probability of being able to keep one's current job, and the consequences of losing the job. If one loses the job, then questions arise about the probability of obtaining another job, as well as the conditions of the subsequent job, most notably the compensation in that job.

Table 12

Probability of Layoff from Full-Time Job by Wave

$\begin{array}{rcccc}\text { Wave } & \text { Year } & \begin{array}{c}\text { Probability } \\ \text { of Layoff }\end{array} & \begin{array}{c}\text { Standard } \\ \text { Deviation }\end{array} & \begin{array}{c}\text { Number of } \\ \text { Observations }\end{array} \\ 2 & 1994 & 7.0 \% & 0.4 \% & 4823 \\ 3 & 1996 & 6.1 & 0.4 & 4177 \\ 4 & 1998 & 5.5 & 0.4 & 3181 \\ 5 & 2000 & 5.0 & 0.4 & 3702 \\ 6 & 2002 & 6.8 & 0.5 & 3026 \\ 7 & 2004 & 5.6 & 0.5 & 2124 \\ 8 & 2006 & 4.9 & 0.4 & 3126 \\ 9 & 2008 & 5.1 & 0.4 & 2587 \\ 10 & 2010 & 11.5 & 0.7 & 2190 \\ 11 & 2012 & 5.2 & 0.4 & 3221 \\ & & & & \\ \text { All } & & 6.2 & 0.1 & 32157\end{array}$


Table 12 indicates the conditional probability of HRS respondents being laid off by a given wave of the study, given that they had been working full-time in the previous survey. In each wave of the HRS, the study asks individuals who were employed in the previous wave if they are still employed by that employer. If they are not still employed by the previous wave's employer, the study asks the individual the reasons why. Multiple responses are permitted, and the individual is considered to have been laid off if the responses include "business closed," "laid off/let go," and/or "would have been laid off."

The table looks only at the first time the individual is laid off during the study; if the individual is laid off more than once during the study, waves after the first layoff are not counted in either the numerator or denominator of the probability. The third column gives the probability of the layoff by year, and the fourth column gives the approximate standard deviation. For instance, the first line says that between the first wave in 1992 and the second wave in 1994, about 7 percent of the respondents who were working full-time in the 1992 survey had been laid off.

In general, the layoff percentages are within a percentage point of the overall mean, which is 6.2 percent over a two-year interval. The one outlier, as might be expected, is the interval between the 2008 and 2010 waves, when the layoff percentage almost doubled and is clearly significantly above the others. This spike in layoff probability does not seem to have persisted, however. By the interval between the 2010 and 2012 waves, the percentage had dropped to the overall mean. Nor does this pattern seem to be an anomaly; the statistics from BLS on major layoffs follow a similar pattern where the layoffs spiked shortly after the Great Recession started and then fell rapidly to roughly pre-recession levels. 
Table 13

Probit for Layoff from Full-Time Job

$\begin{array}{ccr} & \begin{array}{c}\text { Marginal } \\ \text { Effect }\end{array} & \begin{array}{c}\text { Absolute } \\ \text { t-statistic }\end{array} \\ \text { Tenure at employer } & -3.94 \% & 10.98 \\ \text { Tenure squared } & 0.62 & 6.53 \\ \text { Full-time experience } & 0.60 & 1.14 \\ \text { Experience squared } & -0.063 & 0.69 \\ \text { Education: < High school } & 0.69 & 1.77 \\ \text { Some college } & -0.92 & 1.78 \\ \text { College graduate } & -0.61 & 1.54 \\ \text { Advanced degree } & -2.51 & 5.61 \\ \text { Race: black } & -0.51 & 1.45 \\ \text { hispanic } & 0.53 & 1.16 \\ \text { Married } & -0.56 & 1.93 \\ \text { Fair or poor health } & 0.91 & 2.43 \\ \text { Industry: Manufacturing } & 3.54 & 10.21 \\ \text { Government } & -2.98 & 5.68 \\ \text { Occupation: Mgmt/Prof } & 0.88 & 2.36 \\ \text { Pension at employer } & 1.14 & 3.34 \\ \text { Log of wage } & -2.81 & 8.39 \\ \text { Wave 10 } & 0.32 & 1.33 \\ & 5.65 & 10.43\end{array}$

Notes: Tenure and experience are both measured as years divided by 10 . Number of observations: 32,198 
Table 13 gives the results of a probit estimation of the probability of a layoff between the waves on a set of personal and job characteristics, including a binary variable for the 2008-2010 interval. The entries in this table are the marginal effects, that is, the change in the probability from a one unit increase in the corresponding explanatory variable. Thus, the first entry says that the effect of each additional year of tenure is to reduce the probability of a layoff by 0.39 percentage points. This effect of tenure is modified by the entry in the second row, which gives the effect of tenure squared. Comparing the effects of tenure and experience, it is clear that tenure by far the more important determinate of layoff probabilities. Having 10 years of tenure reduces the probability by around 3 percentage points, and having 20 years reduces the probability by around 5 percentage points. This compares with an overall average of 6 percentage points. The effect of experience, on the other hand, is not only insignificant and relatively small numerically, but the direction of the effect is in the opposite direction of what would be expected.

The remaining effects are more or less as expected. More education reduces the probability of layoffs, with the effect being particularly strong for those with advanced degrees. Race does not seem to have a significant effect, while marriage has a marginally negative effect. Standardizing for education and job tenure, those in manufacturing industries have a 3-4 percentage point greater risk of layoffs, and those in management, professional, and white collar occupations (as opposed to blue collar occupations) have around a 1 percentage point greater risk of layoffs. Government workers and employees with pensions in their jobs have around a 3 percentage point reduced risk of layoffs. ${ }^{11}$

The largest effect in this equation, however, is the binary variable indicating the period between wave 9 in 2008 and wave 10 in 2010, which corresponds to the initial period of the

\footnotetext{
${ }^{11}$ Note that because of the nonlinear form of the probit relationship, the total effect of a group of characteristics is not necessarily the sum of the marginal effects.
} 
Great Recession. During this time frame, the probability of layoff rose by 5.7 percentage points on top of a base of 6.2 percentage points. Thus, the spike in layoffs evident in Table 12 carries over largely intact when covariates related to personal and job characteristics are introduced.

In any stochastic model, the realized values of the stochastic variables may vary from their expected values. For instance, the draws for the realized returns on assets may be above or below the ex-ante expected values. The same is true for layoffs. The layoffs in the early years of the Great Recession were higher than expected, but the main question is whether these layoffs resulted in an upward shift in the probabilities of layoffs in future years. The transitory nature of this increase, severe though as it was, suggests that the ex-ante probabilities in future years were probably not affected. Thus the large but temporary increases in layoffs may be treated as positive deviations from a distribution and not as a change in the distribution applicable for the future. This is in contrast to what we believe happened with asset returns, where the long string of negative real short-term interest rates has probably lowered permanently the perceptions of what the distribution of those interest rates looks like.

The next item in the sequence is the question of how long, if an individual is laid off from a full-time job, it takes to find another full-time job. ${ }^{12}$ Fortunately, the HRS has a sequence of questions which attempts to ascertain, month by month, what an individual's employment status is subsequent to a layoff. If an individual is not in the previous job, the study asks the month and year when the individual left that job. If the individual is currently working, the study asks the starting month and year of the current job and the number of hours in the current job. Unless the ending date of the previous job coincides with the starting data of the current job, the study inquires about which months, if any, the individual was working in intermediate jobs, as well as the hours in those jobs. When the information is complete, it is possible to construct a measure of

\footnotetext{
${ }^{12}$ See Rutledge (2014) for a cross sectional analysis based on SIPP data.
} 
the number of months between a layoff and the start of another full-time job, even if the next full-time job begins in a wave after the initial layoff.

Table 14 reports the distribution of the length of the spells before the next full-time employment by the year of the layoff. The column labeled "censored" refers to cases where no full-time employment was observed in the study after the layoff. This can occur either because the individual left the survey before any full-time employment was recorded, or because the individual effectively retired and never re-entered full-time employment. It can also occur in cases where the individual had gaps in the data and had no full-time employment before such a gap.

Table 15 provides the distribution of the lengths of time observed after a layoff for those who did not enter full-time employment during the time they were continuously observed. This table gives the overwhelming impression that the primary cause of censored observations is that individuals never re-entered full-time employment, not that the period of observation ended before a full-time job was observed. For instance, for layoffs in 2002, 28 of the 45 cases of layoffs that year in which subsequent full-employment was not observed had at least 31 months of observation after the layoff. From Table 14, the cases where full-time work was observed after the layoff were strongly skewed toward relatively short periods, and one would expect only a few cases where individuals with censored spells of 31 months or more would eventually be employed full-time. Only for layoffs after 2010 does it appear that the last observed wave of the study may have cut short the period of observation before individuals found other full-time jobs. 
Table 14

Duration of Spells Between Full-Time Jobs After Layoffs

\begin{tabular}{|c|c|c|c|c|c|c|}
\hline \multirow{2}{*}{$\begin{array}{l}\text { Year of } \\
\text { Layoff }\end{array}$} & \multicolumn{5}{|c|}{ Months Until Next Full-Time Job } & \multirow[b]{2}{*}{ Censored } \\
\hline & $0-1$ & $2-6$ & $7-18$ & $19-30$ & $31+$ & \\
\hline 1992 & 19 & 5 & 11 & 7 & 2 & 18 \\
\hline 1993 & 52 & 29 & 36 & 8 & 8 & 61 \\
\hline 1994 & 43 & 38 & 25 & 13 & 10 & 59 \\
\hline 1995 & 31 & 19 & 20 & 3 & 6 & 44 \\
\hline 1996 & 35 & 12 & 13 & 8 & 5 & 47 \\
\hline 1997 & 32 & 21 & 14 & 4 & 4 & 34 \\
\hline 1998 & 29 & 12 & 6 & 2 & 4 & 45 \\
\hline 1999 & 26 & 18 & 18 & 4 & 8 & 35 \\
\hline 2000 & 35 & 6 & 7 & 3 & 1 & 42 \\
\hline 2001 & 22 & 10 & 16 & 2 & 4 & 38 \\
\hline 2002 & 22 & 13 & 15 & 5 & 1 & 45 \\
\hline 2003 & 16 & 5 & 8 & 1 & 3 & 38 \\
\hline 2004 & 19 & 8 & 6 & 4 & 4 & 31 \\
\hline 2005 & 24 & 21 & 12 & 1 & 2 & 33 \\
\hline 2006 & 22 & 17 & 11 & 3 & 4 & 24 \\
\hline 2007 & 13 & 17 & 12 & 1 & 2 & 41 \\
\hline 2008 & 32 & 11 & 10 & 5 & 3 & 59 \\
\hline 2009 & 20 & 10 & 18 & 9 & 1 & 66 \\
\hline 2010 & 17 & 13 & 8 & 3 & 1 & 57 \\
\hline 2011 & 31 & 26 & 7 & 0 & 0 & 52 \\
\hline 2012 & 17 & 13 & 2 & 0 & 0 & 56 \\
\hline All & 557 & 324 & 275 & 86 & 73 & 925 \\
\hline
\end{tabular}

Total number of observed layoffs: 2240 
Table 15

Duration of Observed Spells Without Full-Time Work After a Layoff for Censored Observations

\begin{tabular}{|c|c|c|c|c|c|c|}
\hline \multirow{2}{*}{$\begin{array}{l}\text { Year of } \\
\text { Layoff }\end{array}$} & \multicolumn{5}{|c|}{ Duration of Observed Spell } & \multirow[b]{2}{*}{ Total } \\
\hline & $0-1$ & $2-6$ & $7-18$ & $19-30$ & $31+$ & \\
\hline 1992 & 9 & 1 & 0 & 3 & 5 & 18 \\
\hline 1993 & 14 & 0 & 8 & 2 & 37 & 61 \\
\hline 1994 & 6 & 8 & 3 & 8 & 34 & 59 \\
\hline 1995 & 5 & 0 & 6 & 4 & 29 & 44 \\
\hline 1996 & 4 & 6 & 2 & 6 & 29 & 47 \\
\hline 1997 & 10 & 0 & 6 & 2 & 16 & 34 \\
\hline 1998 & 7 & 1 & 2 & 3 & 32 & 45 \\
\hline 1999 & 4 & 1 & 4 & 1 & 25 & 35 \\
\hline 2000 & 7 & 3 & 3 & 2 & 27 & 42 \\
\hline 2001 & 6 & 0 & 4 & 1 & 27 & 38 \\
\hline 2002 & 2 & 3 & 4 & 8 & 28 & 45 \\
\hline 2003 & 2 & 2 & 9 & 0 & 25 & 38 \\
\hline 2004 & 6 & 1 & 2 & 0 & 22 & 31 \\
\hline 2005 & 6 & 1 & 1 & 1 & 24 & 33 \\
\hline 2006 & 1 & 1 & 1 & 5 & 16 & 24 \\
\hline 2007 & 6 & 0 & 4 & 1 & 30 & 41 \\
\hline 2008 & 6 & 2 & 4 & 6 & 41 & 59 \\
\hline 2009 & 3 & 0 & 9 & 2 & 52 & 66 \\
\hline 2010 & 5 & 3 & 4 & 35 & 10 & 57 \\
\hline 2011 & 8 & 1 & 36 & 7 & 0 & 52 \\
\hline 2012 & 4 & 35 & 17 & 0 & 0 & 56 \\
\hline
\end{tabular}


Table 16

Estimates of Distribution Function for Spells from Layoff until Full-Time Work

\begin{tabular}{|c|c|c|c|c|c|c|}
\hline & $\beta_{\mathrm{p}}$ & $\mathrm{t}$ & $\beta_{\lambda}$ & $\mathrm{t}$ & $\beta_{\mathrm{k}}$ & $\mathrm{t}$ \\
\hline Constant & 0.493 & 2.09 & 2.419 & 6.47 & -0.607 & 3.21 \\
\hline Tenure at Employer & 0.494 & 4.51 & 0.233 & 1.58 & 0.032 & 0.39 \\
\hline Tenure Squared & -0.061 & 2.16 & -0.053 & 1.27 & -0.007 & 0.29 \\
\hline Full-Time Experience & -0.743 & 5.41 & -0.407 & 1.88 & 0.113 & 1.02 \\
\hline Experience Squared & 0.145 & 6.20 & 0.055 & 1.49 & -0.017 & 0.84 \\
\hline \multicolumn{7}{|l|}{ Education: } \\
\hline Less than High School & -0.065 & 0.63 & -0.074 & 0.55 & 0.052 & 0.74 \\
\hline Some College & 0.006 & 0.04 & 0.168 & 0.80 & -0.088 & 0.82 \\
\hline College Graduate & 0.020 & 0.17 & 0.129 & 0.92 & 0.014 & 0.18 \\
\hline Advanced Degree & 0.203 & 1.30 & -0.256 & 1.53 & 0.173 & 1.71 \\
\hline \multicolumn{7}{|l|}{ Race: } \\
\hline Black & -0.041 & 0.37 & 0.369 & 2.54 & 0.058 & 0.74 \\
\hline Hispanic & 0.150 & 1.25 & 0.274 & 1.74 & 0.119 & 1.31 \\
\hline Married & -0.125 & 1.59 & 0.060 & 0.61 & -0.064 & 1.17 \\
\hline Fair or Poor Health & 0.159 & 1.66 & 0.042 & 0.32 & 0.084 & 1.14 \\
\hline \multicolumn{7}{|l|}{ Industry: } \\
\hline Manufacturing & 0.082 & 0.99 & 0.179 & 1.75 & 0.115 & 1.96 \\
\hline Government & 0.682 & 2.93 & 0.467 & 1.15 & -0.077 & 0.38 \\
\hline \multicolumn{7}{|l|}{ Occupation } \\
\hline Management/Prof & -0.146 & 1.42 & 0.050 & 0.39 & 0.036 & 0.54 \\
\hline White Collar & 0.113 & 1.26 & 0.187 & 1.58 & 0.072 & 1.14 \\
\hline Pension in Job & -0.112 & 1.35 & -0.023 & 0.22 & 0.005 & 0.10 \\
\hline Log of wage & -0.219 & 3.21 & -0.022 & 0.25 & 0.020 & 0.41 \\
\hline Trend & 0.292 & 4.60 & -0.312 & 3.49 & 0.129 & 2.78 \\
\hline Square of Trend & -0.084 & 0.67 & -0.299 & 1.83 & 0.207 & 2.29 \\
\hline Great Recession & & & 0.555 & 2.85 & & \\
\hline
\end{tabular}

Notes: See text for an explanation of the three sets of columns. Tenure and experience are both measured as years divided by 10. Trend is (year of layoff - 2002) / 10 and ranges from -1 (1992) to 1 (2012). Great Recession is a binary variable with a value of 1 for 2009 and 2010. The columns labeled $t$ are absolute values of asymptotic t-statistics. Number of observations: 1940. 
The distribution of observed spells from Table 14 suggests a distribution that is strongly declining over time, such as a Weibull distribution. Normally, an estimation of the Weibull distribution takes into account both the distribution of completed spells and the distribution of spells which are censored before completion. The number and lengths of incomplete spells in Table 15, however, appears to be much greater than would be expected from a Weibull distribution, or any distribution with a rapidly falling tail, consistent with Table 14 . These data suggest that the distribution of spells may perhaps best be described by some kind of a compound distribution. In the first stage, let the probability that the individual will effectively retire after the layoff be $p$, with $1-p$ being the probability that the individual will eventually return to full-time work. For those who return to full-time work, let $f(x)$ be the distribution of times until the return. A censored observation, that is, a layoff for which no subsequent return to full-time work is observed, can occur either because the individual has effectively retired or because the subsequent period of observation is too short to capture the return to work.

To make things a little more specific, Let $\mathrm{f}(\mathrm{x})$ be a Weibull distribution, with a cumulative distribution $F(x)=1-\mathrm{e}^{-(\mathrm{x} / \lambda)^{k}}$, where $\mathrm{x}$ is the length of the time between the layoff and the next full-time job. In a Weibull distribution, the $\lambda$ parameter is called the scale parameter and governs how stretched the distribution is along the horizontal axis. The $\mathrm{k}$ parameter is called the shape parameter and, as its name implies, governs the shape of the distribution. For values between 0 and 1 , the Weibull is a continuously declining distribution. The closer the value is to 0 , the sharper the distribution falls. Both the $\lambda$ and the $\mathrm{k}$ parameters must be positive values.

For observations for which a complete spell from the layoff to the beginning of the next full-time job is observed, the log-likelihood value is given by $(1-p) f(x)=(1-p)(k / \lambda)(x / \lambda)^{k-1} e^{-(x / \lambda)^{k}}$, which is simply the probability that the layoff does 
not result in an effective retirement times the conditional probability density for the spell, conditional on a completed spell. For observations for which the layoff does not result in subsequent full-time employment, the log-likelihood value is given by $\mathrm{p}+(1-\mathrm{p}) \mathrm{F}(\mathrm{x})=\mathrm{p}+(1-\mathrm{p})\left[1-\mathrm{e}^{-(\mathrm{x} / \lambda)^{\mathrm{k}}}\right]$. This is simply the probability of retirement plus the probability of an incomplete spell, conditional on the individual returning to full-time work. The overall likelihood value is simply the sum of the likelihood values for these two types of observations.

The likelihood values are thus functions of parameters $\mathrm{p}, \lambda$, and $\mathrm{k}$. But these parameters may in turn be functions of explanatory variables. let $\mathrm{p}=\mathrm{N}\left(\mathrm{X}_{\mathrm{p}} \beta_{\mathrm{p}}\right)$, so that the probability of retirement is a probit relationship dependent on a group of explanatory variables $X_{p}$. This guarantees that the probability lies between 0 and 1 . Similarly, let $\lambda=\exp \left(X_{\lambda} \beta_{\lambda}\right)$ and $k$ $=\exp \left(\mathrm{X}_{\mathrm{k}} \beta_{\mathrm{k}}\right)$, where the exponential functional form guarantees that both $\lambda$ and $\mathrm{k}$ will be greater than 0 , as required for the Weibull distribution. The likelihood function is then maximized with respect to $\beta_{\mathrm{p}}, \beta_{\lambda}$, and $\beta_{\mathrm{k}}$ to obtain estimates.

The results of the estimation are presented in Table 16. A quadratic trend term is included in each of these linear forms to capture any trends in retirement and/or changes in the distribution of spells over time. Most of these trend terms are significant. About the only other terms which reach $95 \%$ confidence in the Weibull distribution are the coefficient for black race in the linear form for $\lambda$ and the coefficient for manufacturing in the linear form for $\mathrm{k}$. A term for layoffs in the 2009-2010 time frame is included in the linear form for $\lambda$ and is significant at better than 99\% confidence. Its coefficient indicates that spells between layoffs and successive full-time work lengthened considerably over this period. Similar coefficients for the other two linear forms were completely insignificant and were dropped from the specification. 
For a typical individual with average characteristics in the sample, these coefficients indicate that, under normal circumstances, there is a $45 \%$ chance that a spell after a layoff before the next full-time job will last less than 3 months, a 16\% chance that the spell will last between 3 and 6 months, and a 17\% chance that it will last between 6 and 12 months. ${ }^{13}$ When the Great Recession variable is factored in, these percentages change to a $34 \%$ chance that the spell will last for less than 3 months, a 14\% chance it will last between 3 and 6 months, and a 17\% chance that it will last between 6 and 12 months. The median duration is normally 3.7 months but rose to 6.5 months for layoffs during the Great Recession.

The question arises whether this increased duration of nonworking spells after a layoff could be perceived as permanent, or whether it was a transitory increase. To answer this question, a binary variable indicating a layoff in the 2011-2012 period was added to the specification in Table 16. Measuring the effects on duration of layoffs during this period is a little tenuous, since the last wave was in 2012 and only relatively short durations would have been completed. Nonetheless, the coefficient of the 2011-2012 layoff variable is of the wrong sign and gives no indication that the duration effects of the Great Recession were long lasting. As with the probability of a layoff, it appears that the increase in duration of spells before the next full-time job was a transitory phenomenon and not a permanent shift in the distribution of durations.

Thus, the Great Recession both increased the probability of being laid off and increased the length of time it took laid-off workers to find other full-time employment.

\footnotetext{
${ }^{13}$ This individual has 11 years of tenure and 32 years of experience, is white with a high school education, is a blue-collar worker in a non-manufacturing industry, had a pension, and had an hourly wage of \$10.18 in 1992 dollars.
} 
Table 17

Fixed Effects Indexed Wage Equation Coefficients

\begin{tabular}{|c|c|c|c|c|}
\hline & Coefficient & $\mathrm{t}$ & Coefficient & $\mathrm{t}$ \\
\hline Constant & 2.015 & 97.03 & 2.014 & 96.04 \\
\hline Tenure at Employer & 0.123 & 13.12 & 0.123 & 12.95 \\
\hline Tenure Squared & -0.009 & 3.52 & -0.009 & 3.41 \\
\hline Full-Time Experience & 0.113 & 8.90 & 0.112 & 8.79 \\
\hline Experience Squared & -0.021 & 9.50 & -0.021 & 9.41 \\
\hline Married & 0.033 & 2.63 & 0.035 & 2.78 \\
\hline Fair or Poor Health & -0.022 & 2.43 & -0.022 & 2.32 \\
\hline Self-Employed & -0.120 & 9.95 & -0.118 & 9.75 \\
\hline \multicolumn{5}{|l|}{ Industry: } \\
\hline Manufacturing & 0.103 & 9.87 & 0.103 & 9.72 \\
\hline Government & 0.052 & 3.13 & 0.050 & 2.97 \\
\hline \multicolumn{5}{|l|}{ Occupation: } \\
\hline Management/Prof & 0.120 & 11.78 & 0.118 & 11.51 \\
\hline White Collar & -0.004 & 0.39 & -0.005 & 0.51 \\
\hline Pension in Job & 0.141 & 19.41 & 0.142 & 19.39 \\
\hline Prior Layoff & -0.073 & 7.52 & -0.075 & 7.33 \\
\hline $\begin{array}{l}\text { Layoff Between } \\
\text { Waves } 9 \text { and } 10\end{array}$ & & & 0.019 & 0.37 \\
\hline Number of Observations & \multicolumn{2}{|c|}{51,924} & \multicolumn{2}{|c|}{51,343} \\
\hline Number of Individuals & \multicolumn{2}{|c|}{15,619} & \multicolumn{2}{|c|}{15,568} \\
\hline
\end{tabular}

Notes: Dependent variable is the log of the wage rate. Tenure and experience are both measured as years divided by 10 . The columns labeled $t$ are absolute values of asymptotic t-statistics. 
The next issue is the nature of the subsequent job, and in particular the wage rate in the subsequent job. Table 17 contains coefficients from fixed effects regressions of wages taken from the HRS. These wages include wages in full-time jobs held in any of the study wave years plus wages in full-time jobs in the job histories collected in the first interview. All wages are indexed to 1992 (the first year of the HRS) using the average weekly earnings series reported in various Economic Reports of the President. The use of fixed effects nets out any differences due to different personal characteristics and only uses information on the wage changes over time for the same individual.

If an individual gets laid off, the wage in the subsequent job should be less, reflecting the loss of tenure. The question of interest here is whether there is an additional effect from having been laid off, relative to leaving a job for other reasons, and furthermore whether this effect was larger for layoffs which happened during the Great Recession. In the table, the first two columns include a term related to whether the individual has ever been laid off in a prior job. The coefficient, which is highly significant, suggests that having been laid off in a prior job results in a 7.3 percent reduction on top of the reduction from the loss of tenure. The last two columns include an additional binary variable which has a value of 1 if the layoff occurred between wave 9 (2008) and wave 10 (2010) of the study, which includes the first two years of the Great Recession. This term is slightly positive, which is the opposite of what might be expected, but it is not significant. The conclusion is that while the Great Recession resulted in a greater probability of being laid off and a longer wait until the next full-time job, it does not appear to have depressed wages in subsequent jobs below the levels which would have occurred anyway with a layoff. 


\section{Conclusions.}

Older workers, with their longer tenure and resulting job security, are not expected to be as vulnerable to a recession as prime age and younger workers. Nevertheless, the Great Recession did have an effect on those who were in their fifties at its outset. Both the probability of a layoff and the length of time it took laid-off workers to find other full-time employment were increased.

Layoffs appear to explain the actual change in employment experienced over the Great Recession. Our findings suggest that compared to the experience of members of older cohorts at the same age, unemployment from layoffs increased by 2.9 percentage points for the Early Boomers during Great Recession period. Meanwhile, the reduction in employment for the Early Boomers was 3 percentage points greater in absolute terms than for the older cohorts. These two changes are approximately equal.

As one might expect from the definition of unemployment, most (around 90 percent) of the unemployed declared themselves to be Not Retired or Partially Retired. In 2010, at the peak of the labor market effects of the Great Recession, about half of those who experienced a layoff reported themselves as Not Retired or Partially Retired, Not Working. This fraction is substantially higher than the values found for older cohorts at the same age. In previous years, one quarter to one third of those in their fifties who experienced a layoff reported they were also Not Retired or Partially Retired and Not Working.

More surprisingly, in 2010, those who experienced a layoff accounted for only about one quarter of those who are Not Retired or Partially Retired and Not Working. While this is 5 to 11 percentage points higher than similar ratios observed for older cohorts, job loss is not the major reason a person declares themselves to be Not Retired or Partially Retired while Not Working. 
Apparently many of those who have left their jobs voluntarily declare themselves to be Not Retired or Partially Retired. During the Great Recession, even more of those who left their employment and in other times would have declared themselves to be retired, instead held on to a subjective connection to the labor market.

A labor market connection for someone who is not working and not unemployed must be quite tenuous. Such an individual who also claims to be not retired or only partially retired probably does not have immediate plans to try to get back to work. There may be several motivations for such individuals to claim they are not retired or only partially retired. It may be that they don't want to admit that they are really retired (in which case they really are retired), or there may be circumstances which cause them to think that they will return to work at some time in the indefinite future. It might be a health problem from which they expect to recover, or a financial shock which leaves them with insufficient assets to fully retire. Some may indeed have planned to return to work after taking a break (Maestas, 2010). In any case, it seems like this group grew as well during the Great Recession; among the Early Boomers in 2010, 17 percent were Not Working but Not Retired or Partially Retired and 6 percent were unemployed, leaving at least 9 percent who were not working and not unemployed but not retired or only partially retired.

To avoid having to rely on subjective expectations based on unspecified circumstances, our multivariate analysis focused on the relation of the Great Recession to employment, layoffs and unemployment, rather than on a measure of retirement status based on subjective responses about retirement status. Between the 2008 and 2010 waves, the layoff percentage almost doubled, rising by 5.7 percentage points on top of a base of 6.2 percentage points. This spike in layoff probability does not seem to have persisted, however. By the interval between the 2010 and 2012 waves, the percentage had dropped to the overall mean. The multivariate analysis also 
suggests that the median duration of unemployment after a layoff is normally 3.7 months, but rose to 6.5 months for layoffs during the Great Recession. As with the probability of a layoff, it appears that the increase in duration of spells before the next full-time job was a transitory phenomenon and not a permanent shift in the distribution of durations.

Although the Great Recession increased the probability of near retirees being laid off and subject to a longer wait until the next full-time job, it does not appear to have depressed wages in subsequent jobs below the levels which would have occurred anyway with a layoff. 


\section{References}

Anderson, Patricia M., Alan L. Gustman and Thomas L. Steinmeier. 1999. "Trends in Male Labor Force Participation and Retirement: Some Evidence on the Role of Pensions and Social Security in the 1970s and 1980s," Journal of Labor Economics 17(4): 757-83.

Burtless, Gary and Barry P. Bosworth. 2013. "Impact of the Great Recession on Retirement

Trends in Industrialized Countries". Boston College, Center for Retirement Research. Working Paper 2013-23.

Chan, Sewin and Ann Huff Stevens "Job Loss and Employment Patterns of Older Workers," Journal of Labor Economics 19(2): 484-521.

Cohan, Peter. 2012. “6 Reasons You Will Never Retire”. Forbes. (June).

Coile Courtney C and Phillip B. Levine. 2011a. "The Market Crash and Mass Layoffs: How the Current Economic Crisis May Affect Retirement." The B.E. Journal of Economic Analysis and Policy, 11(1): 1-42. . 2011b. "Recessions, Retirement, and Social Security." American Economic Review: Papers \& Proceedings 101(3), 23-28.

Copeland, Craig. 2014. "Labor-force Participation Rates of the Population Ages 55 and Older, 2013. EBRI Notes, April, Vol. 35, Number 4. Employee Benefit Research Institute. Council of Economic Advisors. 2014. "The Labor Force Participation Rate Since 2007: Causes and Policy Implications".

Gorodnichenko, Yuriy, Jae Song and Dmitriy Stolyarov. 2013. "Macroeconomic Determinants of Retirement Timing”. NBER Working Paper 19638.

Gustman, Alan L. and Thomas L. Steinmeier. 2000. "Retirement in Dual-Career Families: A Structural Model." with Thomas Steinmeier, Journal of Labor Economics 18 (3): 503-545. 
2009. "How Changes in Social Security Affect Recent Retirement

Trends." Research on Aging 31(2): 261-290.

. 2014. "Integrating Retirement Models: Understanding Household

Retirement Decisions”. Research in Labor Economics 80: 81-114.

Gustman, Alan L., Thomas L. Steinmeier and Nahid Tabatabai. 2014. "The Great Recession, Decline and Rebound in Household Wealth for the Near Retirement Population". Journal of Retirement Fall 2014, 2(2): 27-44.

Johnson, Richard W. 2012. “Older Workers, Retirement and the Great Recession”. New York: Russell Sage Foundation.

Maestas, Nicole. 2010. “Back to Work: Expectations and Realizations of Work After

Retirement. Journal of Human Resources 45(3).

Maestas, Nicole, Kathleen J. Mullen and David Powell. 2013. "The Effect of Local Labor

Demand Conditions on the Labor Supply Outcomes of Older Americans". Rand Working Paper WR-1019.

Rutledge, Mathew W. 2013. "Point of No Return: How Do Financial Resources Affect the Timing of Retirement After a Job Separation”. Boston College, Center for Retirement Research. Working Paper 2013-21.

Rutledge, Mathew W. 2014. "How Long Do Unemployed Older Workers Search for a Job?" Boston College, Center for Retirement Research. Paper No. 14-3. February. 
Appendix:

Retirement of Men vs. Women

Appendix Table 1: Retirement Flows from 2006 to 2012 for Early Boomers: Ages 53-58 in 2006. Males (weighted)

\begin{tabular}{|l|c|c|c|c|c||}
\hline \multirow{2}{*}{ Status in 2006 } & \multicolumn{4}{|c|}{ Status in 2012 } & Row Total \\
\cline { 2 - 6 } & Not Retired & $\begin{array}{l}\text { Partially } \\
\text { Retired }\end{array}$ & $\begin{array}{l}\text { Completely } \\
\text { Retired }\end{array}$ & $\begin{array}{l}\text { Other Not } \\
\text { Working }\end{array}$ & $\begin{array}{l}\text { Status in } \\
2006\end{array}$ \\
\hline Not Retired & 61 & 9 & 20 & 10 & 71 \\
\hline Partially Retired & 15 & 39 & 24 & 22 & 6 \\
\hline Completely Retired & 3 & 3 & 79 & 13 & 11 \\
\hline Other Not Working & 14 & 8 & 52 & 26 & 13 \\
\hline $\begin{array}{l}\text { Column Total } \\
\text { (Status in 2012) }\end{array}$ & 46 & 10 & 30 & 13 & \\
\hline
\end{tabular}

Appendix Table 2: Retirement Flows from 2006 to 2012 for Early Boomers: Ages 53-58 in 2006. Females (weighted)

\begin{tabular}{|c|c|c|c|c|c|}
\hline \multirow{2}{*}{ Status in 2006} & \multicolumn{4}{|c|}{ Status in 2012} & \multirow[b]{2}{*}{$\begin{array}{l}\text { Row Total } \\
\text { Status in } \\
2006\end{array}$} \\
\hline & Not Retired & $\begin{array}{l}\text { Partially } \\
\text { Retired }\end{array}$ & $\begin{array}{l}\text { Completely } \\
\text { Retired }\end{array}$ & $\begin{array}{l}\text { Other Not } \\
\text { Working }\end{array}$ & \\
\hline Not Retired & 55 & 10 & 23 & 12 & 54 \\
\hline Partially Retired & 21 & 35 & 29 & 15 & 13 \\
\hline Completely Retired & 3 & 6 & 84 & 7 & 11 \\
\hline Other Not Working & 9 & 9 & 40 & 43 & 22 \\
\hline $\begin{array}{l}\text { Column Total } \\
\text { (Status in 2012) }\end{array}$ & 35 & 12 & 34 & 18 & 100 \\
\hline
\end{tabular}


Appendix Table 3: Measures of Differences in Retirement, Unemployment and Related Outcomes Over Six Year Period: For Measures of Change, the denominator is total population ages 53 to 58 who were working full-time in the base year. (weighted)

\begin{tabular}{|c|c|c|c|c|c|c|}
\hline & $\begin{array}{c}\text { Original } \\
\text { HRS } 1994\end{array}$ & $\begin{array}{l}\text { Original } \\
\text { HRS } 2000\end{array}$ & $\begin{array}{c}\text { War- } \\
\text { babies } \\
2000\end{array}$ & $\begin{array}{c}\text { War- } \\
\text { babies } \\
2006\end{array}$ & $\begin{array}{c}\text { Early } \\
\text { Boomers } \\
2006\end{array}$ & $\begin{array}{c}\text { Early } \\
\text { Boomers } \\
2012\end{array}$ \\
\hline \multicolumn{7}{|c|}{ Change in Individual's Retirement Status- Full-time in the base year } \\
\hline $\begin{array}{l}\text { 1- Difference in Percent not retired, } \\
\text { end year minus base year }\end{array}$ & \multicolumn{2}{|r|}{-39} & \multicolumn{2}{|r|}{-39} & \multicolumn{2}{|r|}{-41} \\
\hline $\begin{array}{l}\text { 2- Difference in Percent partially } \\
\text { retired, end year minus base year }\end{array}$ & \multicolumn{2}{|r|}{10} & \multicolumn{2}{|r|}{11} & \multicolumn{2}{|r|}{9} \\
\hline $\begin{array}{l}\text { 3- Difference in Percent completely } \\
\text { retired, end year minus base year }\end{array}$ & \multicolumn{2}{|r|}{19} & \multicolumn{2}{|r|}{20} & \multicolumn{2}{|r|}{21} \\
\hline $\begin{array}{l}\text { 4- Difference in percent other not } \\
\text { working, end year minus base year }\end{array}$ & \multicolumn{2}{|r|}{10} & \multicolumn{2}{|r|}{9} & \multicolumn{2}{|r|}{10} \\
\hline 5- Percent reducing work & \multicolumn{2}{|r|}{38} & \multicolumn{2}{|r|}{39} & \multicolumn{2}{|r|}{40} \\
\hline 6- Percent working same amt. & \multicolumn{2}{|r|}{62} & \multicolumn{2}{|r|}{61} & \multicolumn{2}{|r|}{59} \\
\hline 7- Percent increasing work & \multicolumn{2}{|r|}{0} & \multicolumn{2}{|r|}{0} & \multicolumn{2}{|r|}{0} \\
\hline $\begin{array}{l}\text { 8- Difference between percent } \\
\text { working more than } 35 \text { hours per week, } \\
\text { end year minus base year }\end{array}$ & \multicolumn{2}{|r|}{-35} & \multicolumn{2}{|r|}{-38} & \multicolumn{2}{|r|}{-38} \\
\hline $\begin{array}{l}9 \text { - Difference between percent with } \\
16+\text { years of tenure in the end year } \\
\text { and } 10+\text { years in the base year }\end{array}$ & \multicolumn{2}{|r|}{-27} & \multicolumn{2}{|r|}{-26} & \multicolumn{2}{|r|}{-24} \\
\hline $\begin{array}{l}\text { 10- Percent reporting layoff any time } \\
\text { in } 6 \text { year period }\end{array}$ & \multicolumn{2}{|r|}{14} & \multicolumn{2}{|r|}{15} & \multicolumn{2}{|r|}{20} \\
\hline $\begin{array}{l}\text { 11- Percent reporting unemployment } \\
\text { any time in the } 6 \text { year period }\end{array}$ & \multicolumn{2}{|r|}{4} & \multicolumn{2}{|r|}{5} & \multicolumn{2}{|r|}{11} \\
\hline $\begin{array}{l}\text { 12- Percent accepted window plan any } \\
\text { time in } 6 \text { year period }\end{array}$ & \multicolumn{2}{|r|}{6} & \multicolumn{2}{|r|}{4} & \multicolumn{2}{|r|}{4} \\
\hline $\begin{array}{l}\text { 13- Entering SSDI between the base } \\
\text { year and end year }\end{array}$ & \multicolumn{2}{|r|}{3} & & 5 & & 5 \\
\hline
\end{tabular}


Appendix Table 4: Measures of Differences in Retirement, Unemployment and Related Outcomes Over Six Year Period: For Measures of Change, the denominator is total population ages 53 to 58 who were working full-time and had 10 or more years of tenure in the base year. (weighted)

\begin{tabular}{|c|c|c|c|c|c|c|}
\hline & $\begin{array}{l}\text { Original } \\
\text { HRS } 1994\end{array}$ & $\begin{array}{c}\text { Original } \\
\text { HRS } 2000\end{array}$ & $\begin{array}{l}\text { War- } \\
\text { babies } \\
2000\end{array}$ & $\begin{array}{c}\text { War- } \\
\text { babies } \\
2006\end{array}$ & $\begin{array}{c}\text { Early } \\
\text { Boomers } \\
2006 \\
\end{array}$ & $\begin{array}{c}\text { Early } \\
\text { Boomers } \\
2012 \\
\end{array}$ \\
\hline \multicolumn{7}{|c|}{ Change in Individual's Retirement Status- Full-time and Long term* job in the base year } \\
\hline $\begin{array}{l}\text { 1- Difference in Percent not retired, end } \\
\text { year minus base year }\end{array}$ & \multicolumn{2}{|c|}{-42} & \multicolumn{2}{|c|}{-41} & \multicolumn{2}{|r|}{-42} \\
\hline $\begin{array}{l}\text { 2- Difference in Percent partially retired, } \\
\text { end year minus base year }\end{array}$ & \multicolumn{2}{|c|}{10} & \multicolumn{2}{|c|}{10} & \multicolumn{2}{|r|}{8} \\
\hline $\begin{array}{l}\text { 3- Difference in Percent completely } \\
\text { retired, end year minus base year }\end{array}$ & \multicolumn{2}{|c|}{23} & \multicolumn{2}{|c|}{23} & & 26 \\
\hline $\begin{array}{l}\text { 4- Difference in percent other not } \\
\text { working, end year minus base year }\end{array}$ & \multicolumn{2}{|c|}{9} & \multicolumn{2}{|c|}{7} & & 9 \\
\hline 5- Percent reducing work & \multicolumn{2}{|c|}{42} & \multicolumn{2}{|c|}{41} & & 42 \\
\hline 6- Percent working same amt. & \multicolumn{2}{|c|}{58} & \multicolumn{2}{|c|}{59} & & 58 \\
\hline 7- Percent increasing work & \multicolumn{2}{|c|}{0} & \multicolumn{2}{|c|}{0} & & 0 \\
\hline $\begin{array}{l}\text { 8- Difference between percent working } \\
\text { more than } 35 \text { hours per week, end year } \\
\text { minus base year }\end{array}$ & \multicolumn{2}{|c|}{-39} & \multicolumn{2}{|c|}{-40} & & -42 \\
\hline $\begin{array}{l}\text { 9- Difference between percent with } 16+ \\
\text { years of tenure in the end year and } 10+ \\
\text { years in the base year }\end{array}$ & \multicolumn{2}{|c|}{-50} & \multicolumn{2}{|c|}{-48} & & -49 \\
\hline $\begin{array}{l}\text { 10- Percent reporting layoff any time in } 6 \\
\text { year period }\end{array}$ & \multicolumn{2}{|c|}{10} & \multicolumn{2}{|c|}{9} & & 14 \\
\hline $\begin{array}{l}11 \text { - Percent reporting unemployment any } \\
\text { time in the } 6 \text { year period }\end{array}$ & \multicolumn{2}{|c|}{3} & \multicolumn{2}{|c|}{3} & & 8 \\
\hline $\begin{array}{l}\text { 12- Percent accepted window plan any } \\
\text { time in } 6 \text { year period }\end{array}$ & \multicolumn{2}{|c|}{10} & \multicolumn{2}{|c|}{6} & & 6 \\
\hline $\begin{array}{l}\text { 13- Entering SSDI between the base year } \\
\text { and end year }\end{array}$ & \multicolumn{2}{|c|}{3} & \multicolumn{2}{|c|}{4} & & 5 \\
\hline
\end{tabular}

*Long term job is the job with 10 or more years of tenure. 